type in footnotes for common names which are already transliterated into English in the text. We have seen the Tibetan cryptic spell written in a variety of ways in travellers' narratives, but we do not remember to have seen it rendered "Om mane padme hom," as it repeatedly appears here. On the other hand, Mr. Johnston tells the story of his journeyings pleasantly and effectively, and with much literary skill; and he gives in appendices three pages of valuable vocabularies in the dialects of five tribes (Yung-ning Liso, Yung-ning Moso, Muli [Njong], Pa-u-rong Hsifan, and $\mathrm{Pa}$-u-rong Lolo); also some statistical and fiscal information translated at first hand from the official records of Mount Omei and the Ssuch'uan provincial chronicles.

$\mathrm{He}$ is a believer in the reality of the "Yellow Peril," and picturesquely supports the tragic conjecture that the Western peoples some day may be crushed out of existence and their yellow doom of the conqueror in this fight is that he must never sheath his sword. New challengers are ever pressing into the lists, and the challenged must ever go armed and with lance in rest." L. A. IV.

\section{INTERNATIONAL PHYSICS.}

RECENT work at the Bureau international des Poids et Mesures is described in the volumes referred to below. ${ }^{1}$ The volumes, like their predecessors, are full of interest to the physicist concerned with exact measurements, and are a monument to the services rendered to science by the International Committee of Weights and Measures and the director and staff of the well-known institution at Sèvres. Though twenty-two nations participate in the work of the committee, the total budget of the institution is limited by statute to $4000 l$. a year. This sum is made up by contributions by the different nations on

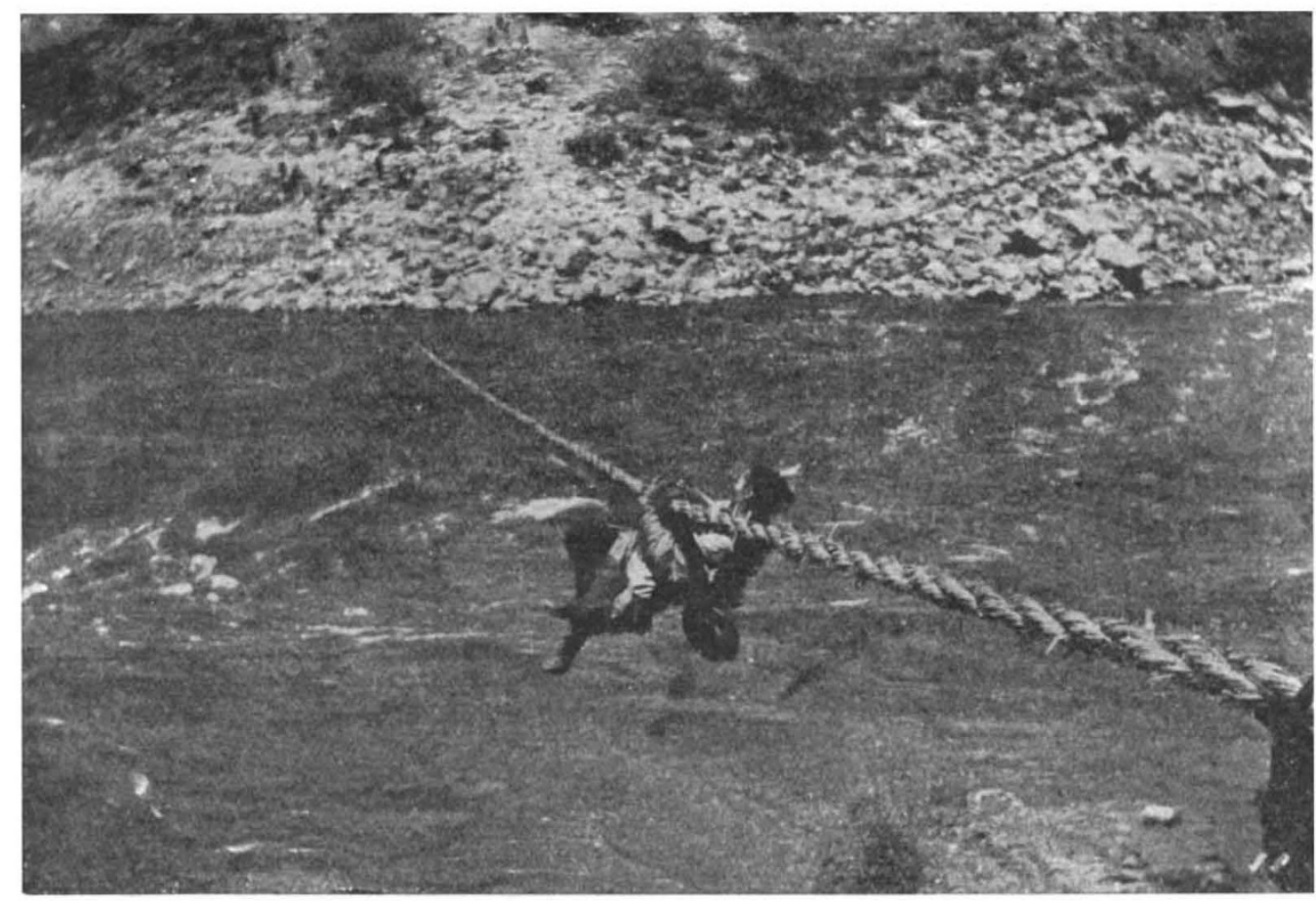

Crossing the Yalung River. Erom "From Peking to Mandalay.'

successors scarcely regret their disappearance any more than we ourselves regret the extinction of the dinotherium or the ichthyosaurus. "Why indeed should they?" he asks. "When we consider how seldom the memory even of our own dead ancestors touches our sympathies or prompts an affectionate thought, it will not seem strange that in days to come the victorious Yellow man mav regard the extinct White man with no more emotion than the visitor to a museum now regards the wire-linked bones of a prehistoric monster. No creature that is doomed to failure in the struggle for existence need look to the conquerors for the least sign of pity or sympathy. No less cheerfully warbles the thrush because the great auk will flap his ineffectual wings no more. Even the crocodile refrains from shedding tears over the fossil remains of the Triassic stagonolepis. It behoves us to remember that victory in the struggle for existence is not a victory once and for all. The a scale based on their respective populations, the latter being multiplied in each case by an appropriate factor, $\mathrm{I}, 2$, or 3 , according as the metric system is not employed, is permissive, or is obligatory. The United Kingdom recently passed from Class (I) to Class (2), and, paying only on the population of the mother country, contributed, in 1907, 6339 francs, or about one-sixteenth of the total sum required.

After some interesting correspondence between the International Committee and the British Government on the question of the representation of the colonies belonging to this country, Canada has just entered the convention as an autonomous nation having its own delegate.

At the present time Great Britain is in the happy

1 "Procès-verbaux des Séances du Comité international de; Poids et Mesures." Deuxième Série. Tome iv.

"Travaux et Mémoires du Bureau international des Poi ls et Mesures." Tome xiii. (Paris: Gauthier-Villars, 1907.)

$$
\text { NO. 2042, VOL. 79] }
$$


position of being the only nation having two representatives on the committee. The circumstances leading to this are detailed in the "Procès-verbaux." The two members are Major MacMahon, F.R.S., and Sir David Gill, K.C.B., F.R.S.

One of the most important pieces of work recently completed at the bureau is the new study of the relation between the metre and the wave-length of the red cadmium line. The classic research of Messrs. Michelson and Benoit fifteen years ago laid the foundation of a whole system of independent controls on the invariability of the prototype. Although the maximum divergence of the three independent determinations made was only one micron (o.oor $\mathrm{mm}$.), and the probable error of the mean considerably less, ret it was felt desirable to repeat the work with the highest possible refinements. This has been done by Messrs. Benoit, Perot, and Fabry, employing a totally different type of interference fringes from those used in the earlier work. By this change and by the use of " invar," the laborious "build-up " process of the older method has been greatly shortened, and the precision of the measurements much enhanced. The results may be stated as follows after all corrections have been applied:

Mean of older determinations,

$$
\text { I metre }=\text { I } 553164^{\circ} 03 \lambda_{\mathrm{R}} \text { or } \lambda_{\mathrm{R}}=0 \mu^{\circ} 64384700
$$

New determinations,

$$
\text { I metre }=\text { I } 553 \mathrm{I} 64 \cdot \mathrm{I} 3 \lambda_{\mathrm{R}} \text { or } \lambda_{\mathrm{R}}=0 \mu \cdot 64384696
$$

the measurements being made in dry air at $15^{\circ} \mathrm{C}$. and under $760 \mathrm{~mm}$. pressure.

Among many other matters of interest in the "Proces-verbaux" is an appreciation of the spectroscopist Thalen, formerly the representative of Sweden on the International Committee, written by his successor, M. Hasselberg. Ifter the application of certain corrections, the author shows that the agreement of Thalen's measurements of the wave-lengths of the three principal cadmium rays with those of Michelson is extraordinarily close. Rowland's values are higher in each case by about one part in fifty thousand.

An appendix deals with the behaviour of nickel steel standards of length. According to the latest investigations, a metre bar of the alloy invar, annealed in the usual way at $40^{\circ} \mathrm{C}$. for many hours, grow's after this treatment, at first somewhat rapidly for work of the highest precision-a micron in ino days-and afterwards at a diminishing rate. A curve is given showing that a bar which has been under observation for 4000 days has not yet quite ceased to change. During the whole period, however, its change is less than fifteen microns. There is no need to emphasise the enormous utility of invar for many purposes, though this phenomenon would appear to render it less suitable for absolute standards than was once supposed.

Passing now to the volume of the "Travaux et Mémoires," we find the papers included in it are six in number. Three of these relate to work done some time ago by Dr. Chappuis before his departure from Sèvres, the first being an account of further studies on the gas thermometer. This is followed by full descriptions of his now classic researches on the dilatation of water and of mercury. The first paper, of sixty-six pages, deals with a repetition of the wellknown experiments which led to the adoption of the hydrogen scale as the recognised international standard of temperature over ordinary ranges. Using both the original large reservoir of platinum-iridium and one of hard glass, values were obtained for the coefficient of expansion of hvdrogen under one metre initial pressure and at constant volume, substantially identical with those found earlier. No perceptible difference of "march" was found between the constant-volume and constant-pressure hydrogen scales between $0^{\circ}$ and $100^{\circ}$. Many data are also given for nitrogen and carbonic acid.

An elaborate paper by M. Daniel Berthelot dis. cusses the theory of the gas thermometer and th: thermodynamic scale. It is proposed to deal with this paper in a later article on thermometry.

Other papers full of great practical interest deal with the general methods of standardisation of divided scales and of boxes of weights. These give, in a summarised form, all the results of the unrivalled experience of Messrs. Benoit and Guillaume and the Sèvres laboratory on these points. The remarks of Dr. Benoit in the early pages of his paper on the standardisation of weights should be studied by every construclor of weights of precision.

\section{NOTES}

Sir James Dewar, F.R.S., has been elected an honorary member of the German Chemical Society.

Dr. F. W. PAYY, F.R.S., consulting physician to Guy's Ilospital, has been awarded the Godard prize of rooo francs by the Paris Academy of Medicine, for his works on carbohydrates and diabetes.

TuE death is announced, at fifty-one ycars of age, of Dr. Giuseppe Ciscato, professor of theoretical geodesy in the Lniversity of Padua.

A special general meeting of the Geological Society will be held on Wednesday, February 10, 1909, in order to consider the result of the vote of the fellows on the question of the admission of women into the society.

IVE learn from Science that Prof. E. B. Poulton, F.R.S., will give the annual address before the Entomological Socicty of America at its Baltimore meeting on December $3 \mathrm{r}$. The title of the address will be "Minicry in the Butterflics of North America."

DR. H. BRERETON BAKER, F.R.S., Lee's reader in chemistry in the University of Oxford, will deliver the Wilde lecture of the Manchester Literary and Philosophical Society on March 9, the subject being "The Influence of Moisture on the Combination of Gases."

Tile Broca prize of 1500 francs for 1908 has been awarded by the Anthropological Society of Paris to Dr. Paul Rivet. The prize was founded in $188 \mathrm{I}$ by Madame Paul Broca, and is awarded for the best memoir on human anatomy, comparative anatomy, or physiology in relation to anthropology. The next award will be made in 1910

A movement, supported by the Linnean Society of New South Wales, is on foot to approach the Australian Government with the object of having Barrow Island, sixty miles off the north-west coast, set apart as a fauna reserve. The island, which is remarkable for its kangaroo, bandicoot, rat, and wren, none of which occurs on the mainland, is likely to be leased for sheep-farming, to the detriment of the fauna. The wise policy of the Crown's retention of islands as sanctuaries for wild life is being amply justified by the experiences of New Zealand and the United States, and the Barrow Island fauna is worth effort to save.

TuE Academy of Natural Sciences of Philadelphia has appointed Dr. A. E. Brown as its delegate to the University of Cambridge Darwin memorial celcbration. 